\title{
Antitranspirant, Water Stress, and Growth Retardant Influence Growth of Golden Pothos
}

\author{
Yin-Tung Wang, Kuo-Hsiun $\mathrm{Hsiao}^{2}$, and Lori L. Gregg ${ }^{3}$ \\ Texas A\&M University Agricultural Research and Extension Center, \\ 2415 East Highway 83, Weslaco, TX 78596
}

Additional index words. Epipremnum aureum, propagation, plant growth regulator, uniconazole, foliage plant

Abstract. Cuttings of Epipremnum aureum (Linden \& André) Bunt. were soaked for 5 seconds in $5 \%$ Folicote or Stressguard antitranspirant solution, planted immediately or after 6 hours, and misted or not misted during the daylight hours for 2 weeks. Neither antitranspirant affected the growth of misted cuttings. However, in nonmisted cuttings, Folicote resulted in delayed first leaf unfolding and small plants. Misting improved shoot growth relative to not misting. In a second experiment, Stressguard sprayed on leaves of stock plants resulted in slow growth of cuttings taken from them, while Folicote had no effect. Water stress induced by delayed planting resulted in water loss and slow lateral shoot growth in both experiments. Application of uniconazole at the four-leaf stage at 0.05 to $0.4 \mathrm{mg} / 0.5$-liter pot reduced stem elongation, leaf count, and the length of nodal roots. Uniconazole increased individual leaf size on the main shoot and promoted the growth of basal lateral shoots. While stem and total plant dry weights were reduced, total leaf dry weight was not affected by uniconazole. Uniconazole continued to provide good control on the elongation of newly emerged lateral shoots and promoted the production of more and larger leaves when evaluated 4 weeks after the main shoot was severed above the fourth basal node. Chemical name used: (E)-1-(p-chlorophenyl)-4,4-dimethyl-2-(1,2,4-trizol-1-yl)-1-penten-3-ol (uniconazole).

Most tropical plant species are propagated by cuttings, including leaf or shoot cuttings, single-node leaf-bud cuttings, and cane cuttings (stem cuttings without foliage). Cuttings of Epipremnum aureum are shipped unrooted domestically and internationally in large quantity. Conover (1986) suggests that growers pack or stick cuttings within $4 \mathrm{~h}$ of harvest. Short holding time between harvest and sticking reduces desiccation and water stress. Temperature and duration in storage had a drastic effect on leaf retention and root production in Codiaeum variegatum (L.) Blume var. Craigii cuttings (Wang, 1987b). Stored Philodendron scandens oxycardium (Schott) Bunt. and E. aureum 'Marble Queen' cuttings grew less than cuttings placed in a mist propagation bed immediately after being received (Poole and Conover, 1988).

Received for publication 18 June 1991. Accepted for publication 9 Oct. 1991. The cost of publishing this paper was defrayed in part by the payment of page charges. Under postal regulations, this paper therefore must be hereby marked advertisement solely to indicate this fact.

${ }^{1}$ Associate Professor.

${ }^{2}$ Visiting Horticulturist. Current address: Chia-Yi Home Economics Senior High School, Chia-Yi, Taiwan, R.O.C.

${ }^{3}$ Technician II.
Antitranspirants, when applied to leaves, have the potential to reduce transpiration rate and water loss (Martin and Link, 1973, 1978; Nitzscheet et al., 1991). However, an antitranspirant was found ineffective in increasing percentage of rooting and root quality of Ligustrum japonicum Thunb. and Dendranthema grandiforum (Ramat.) Kitamura cuttings rooted in a mist propagation bed (Baggott and Joiner, 1974).

Growth retardants have been found to be effective in controlling stem elongation of

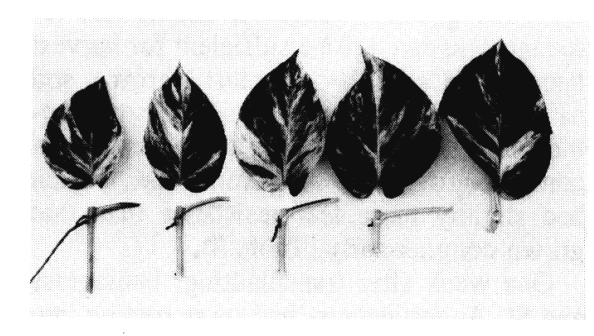

Fig. 1. Effect of uniconazole on leaf size and length of internode of golden pothos. Note that plants receiving uniconazole had short nodal roots. From left, plants receiving $0,0.05,0.1$, 0.2 , or $0.4 \mathrm{mg}$ uniconazole $/ 100 \mathrm{ml}$ water per 0.5 -liter pot. 
Table 1. Effects of a brief soak of cuttings in an antitranspirant solution, delay in planting, and mist on the growth of golden pothos from single-node cuttings. There was no interaction between any two factors or among all factors at $\alpha=0.05$.

\begin{tabular}{|c|c|c|c|c|c|c|}
\hline Variable & $\begin{array}{c}\text { Days to } \\
\text { unfolding }\end{array}$ & $\begin{array}{c}\text { Leaf } \\
\text { no. }\end{array}$ & $\begin{array}{c}\text { Area of } \\
\text { top leafy } \\
\left(\mathrm{cm}^{2}\right)\end{array}$ & $\begin{array}{l}\text { Total } \\
\text { leaf } \\
\text { area } \\
\left(\mathrm{cm}^{2}\right)\end{array}$ & $\begin{array}{c}\text { Stem } \\
\text { length } \\
(\mathrm{cm})\end{array}$ & $\begin{array}{c}\text { Shoot } \\
\text { fresh wt } \\
\text { (g) }\end{array}$ \\
\hline \multicolumn{7}{|l|}{ Mist } \\
\hline \multicolumn{7}{|l|}{ Antitranspirant } \\
\hline None & $35 a^{x}$ & $3.9 \mathrm{a}$ & $42 \mathrm{a}$ & $116 \mathrm{ab}$ & $9.4 \mathrm{a}$ & $7.5 \mathrm{ab}$ \\
\hline Stressguard & $30 \mathrm{a}$ & $4.1 \mathrm{a}$ & $43 a$ & 133 a & $9.4 \mathrm{a}$ & $8.4 \mathrm{a}$ \\
\hline Folicote & 32 a & $3.8 \mathrm{a}$ & $40 \mathrm{a}$ & $109 \mathrm{~b}$ & $8.3 \mathrm{a}$ & $6.9 \mathrm{~b}$ \\
\hline \multicolumn{7}{|l|}{ Time of planting } \\
\hline Immediately & $26^{* *}$ & $4.3^{* *}$ & 43 & $137^{* *}$ & $10.7^{* *}$ & $8.7^{* *}$ \\
\hline Delayed $6 \mathrm{~h}$ & 39 & 3.4 & 41 & 100 & 7.1 & 6.3 \\
\hline \multicolumn{7}{|l|}{ No mist } \\
\hline \multicolumn{7}{|l|}{ Antitranspirant } \\
\hline None & $33 \mathrm{~b}$ & $3.6 \mathrm{a}$ & $37 a$ & 103 a & $7.6 \mathrm{a}$ & $6.5 \mathrm{a}$ \\
\hline Stressguard & $34 \mathrm{~b}$ & $3.6 \mathrm{a}$ & $37 \mathrm{a}$ & 92 a & $5.5 \mathrm{~b}$ & $5.6 \mathrm{a}$ \\
\hline Folicote & $42 a$ & $2.7 \mathrm{~b}$ & $30 \mathrm{~b}$ & $66 \mathrm{~b}$ & $4.0 \mathrm{~b}$ & $4.0 \mathrm{~b}$ \\
\hline \multicolumn{7}{|l|}{ Time of planting } \\
\hline Immediately & $29^{* *}$ & $3.6^{* *}$ & $38^{* *}$ & $104^{* *}$ & $6.8^{* *}$ & $6.5^{* *}$ \\
\hline Delayed $6 \mathrm{~h}$ & 43 & 2.9 & 32 & 71 & 4.6 & 4.3 \\
\hline Mist vs. no mist & * & ** & ** & $* *$ & $* *$ & ** \\
\hline
\end{tabular}

${ }^{x}$ Days from planting to the unfolding of the first leaf blade.

${ }^{y}$ Area of the distal, fully expanded leaf.

'Mean separation in columns within this factor by Duncan's multiple range test, $\alpha=0.05$.

***Two means within each column and factor significantly different at $\alpha=0.05$ and 0.01 , respectively, $\mathrm{F}$ test.

Table 2. Effect of spraying antitranspirant on stock plants before cutting collection and of water stress on the growth of golden pothos from single-node cuttings. There was no interaction between the two factors at $\alpha=0.01$.

\begin{tabular}{lllll}
\hline \hline Variable & $\begin{array}{c}\text { Area of } \\
\text { top leaf } \\
\left(\mathrm{cm}^{2}\right)\end{array}$ & $\begin{array}{c}\text { Total leaf } \\
\text { area } \\
\left(\mathrm{cm}^{2}\right)\end{array}$ & $\begin{array}{c}\text { Stem length } \\
(\mathrm{cm})\end{array}$ & $\begin{array}{c}\text { Shoot } \\
\text { fresh wt } \\
(\mathrm{g})\end{array}$ \\
\hline $\begin{array}{l}\text { Antitranspirant } \\
\quad \text { None }\end{array}$ & $47 \mathrm{ab}^{\mathrm{y}}$ & $141 \mathrm{a}$ & $7.4 \mathrm{a}$ & $8.4 \mathrm{a}$ \\
$\quad \begin{array}{l}\text { Stressguard } \\
\text { Folicote }\end{array}$ & $44 \mathrm{~b}$ & $113 \mathrm{~b}$ & $5.5 \mathrm{~b}$ & $6.6 \mathrm{~b}$ \\
$\begin{array}{l}\text { Time of planting } \\
\text { Immediately }\end{array}$ & $50 \mathrm{a}$ & $135 \mathrm{a}$ & $7.1 \mathrm{a}$ & $8.3 \mathrm{a}$ \\
Delayed 6 h & $54^{* *}$ & $148^{* *}$ & $7.0^{\text {NS }}$ & $9.1^{* *}$ \\
\hline
\end{tabular}

${ }^{2}$ Area of the distal, fully expanded leaf.

y Mean separation in columns within this factor by Duncan's multiple range test, $\alpha=0.05$

$\mathrm{NS}, *, *$ Two means within each column not significantly different or significantly different at $\alpha=0.05$ and 0.01 , respectively, $F$ test.

some foliage plants, thereby increasing the plants' aesthetic value (Wang, 1987a; Wang and Blessington, 1990). Producing golden pothos with short internodal length facilitates management of stock plants, since less space will be needed.

The objective of this study was to determine the effect of two antitranspirants and delayed planting on the propagation of golden pothos by single-node leaf-bud cuttings under misted and nonmisted conditions. The effects of a plant growth retardant on plant morphology were also investigated.

Misting-antitranspirant-delayed planting (Expt. 1). Epipremnum aureum 'Golden Pothos' hanging baskets were grown in Sunshine No, 1 medium (Fisons, Vancouver, B.C.) under a maximum photosynthetic photon flux (PPF) of $410 \mu \mathrm{mol} \cdot \mathrm{m}^{-2} \cdot \mathrm{s}^{-1}$ and fertilized once a week with a $24 \mathrm{~N}-3.5 \mathrm{P}-13.3 \mathrm{~K}$ water-soluble fertilizer at $0.83 \mathrm{~g} \cdot$ liter $^{-1}$ (Wang, 1990) until leaching occurred. Cuttings were collected from those stock plants following the guidelines of Wang and Boogher (1988) and Wang (1990). In brief, cuttings the cuttings were placed in a mist propagation bed for 2 weeks and the other half were moved directly to a greenhouse bench, having a maximum $\mathrm{PPF}$ of $370 \mu \mathrm{mol} \cdot \mathrm{m}^{-2} \cdot \mathrm{s}^{-1}$ and air at 35C (maximum day)/15C (minimum night); the cuttings were watered as needed. Cuttings received the same fertilization regime as the stock plants after the first 2 weeks. The design was a split plot with misting being the main plot. Each treatment was replicated four times with five plants as an experimental unit. The dates of first leaf unfolding were recorded. Plants were evaluated 11 weeks following planting and leaf count, area of the distal matured leaf, total leaf area, stem length, and shoot fresh weight were recorded.

Neither antitranspirant had any effect on plant growth when cuttings were misted for 2 weeks when compared with the untreated (Table 1), possibly because cuttings were placed in the mist bed before the antitranspirants had dried and were washed off leaves. For cuttings that were not misted, dipping them in Folicote delayed first leaf unfolding and resulted in slow shoot development. Stressguard had less of an effect than Folicote in restricting stem growth and resulted in a stem only $28 \%$ shorter than the control. Folicote reportedly reduced water loss from cuttings by an average of $39 \%$ but depressed plant weight and resulted in small leaf area of chrysanthemum (Martin and Link, 1978). Another antitranspirant, Vapor Gard, was found to reduce leaf net photosynthesis in young apple leaves but did not affect shoot growth in 21 days (Weller and Ferree, 1978). Allowing Folicote to dry on nonmisted golden pothos cuttings may have similarly reduced the ability of the single leaf on a cutting to undergo normal photosynthesis, thereby resulting in slow growth. Folicote coating on the stem cut surface may have blocked initial water uptake, resulting in slow leaf emergence.

Cuttings dipped in Folicote or Stressguard and left to dry for $6 \mathrm{~h}$ before being planted lost $0.30 \pm 0.04$ and $0.29 \pm 0.03 \mathrm{~g}$ of water, respectively, whereas the controls lost an average of $0.39 \pm 0.04 \mathrm{~g}$ of water per cutting (significantly different treated cuttings at $P<0.05)$. Since the treated cuttings were dipped in an antitranspirant solution but control cuttings were not dipped in water, the reduced water loss from treated cuttings simply could be due to the presence of a water film on the treated leaf surfaces that reduced the internal water loss from the treated leaves.

Regardless of mist treatment, planting cuttings immediately following collection accelerated the unfolding of the first leaves by nearly 2 weeks and promoted shoot growth, resulting in more leaves, larger total leaf area, $50 \%$ longer stems, and heavier fresh weights when compared with cuttings stressed by the delayed planting (Table 1). The beneficial effect of misting in promoting shoot growth was consistent with that reported previously (Wang, 1990).

Spraying antitranspirant on stock plantcutting growth (Expt. 2). In order to elimi- 
Table 3. Effect of uniconazole soil drench on growth of golden pothos. Plants were produced one per 0.5-liter pot.

\begin{tabular}{|c|c|c|c|c|c|c|c|c|c|c|c|c|c|c|c|}
\hline \multirow{3}{*}{$\begin{array}{l}\text { Uniconazole } \\
\text { (mg/pot) }\end{array}$} & \multirow{3}{*}{$\begin{array}{l}\text { Stem } \\
\text { longation } \\
(\mathrm{cm})\end{array}$} & \multirow{3}{*}{$\begin{array}{c}\text { No. } \\
\text { lateral } \\
\text { shoots }\end{array}$} & \multirow{3}{*}{$\begin{array}{l}\text { No. } \\
\text { new } \\
\text { leaves }\end{array}$} & \multicolumn{7}{|c|}{ Leaf area $\left(\mathrm{cm}^{2}\right)$} & \multirow{3}{*}{$\begin{array}{c}\text { Total } \\
\text { leaf } \\
\text { area } \\
\left(\mathrm{cm}^{2}\right) \\
\end{array}$} & \multirow{3}{*}{$\begin{array}{l}\text { Length of } \\
\text { youngest } \\
\text { elongated } \\
\text { internode } \\
(\mathrm{cm})\end{array}$} & \multirow{2}{*}{\multicolumn{3}{|c|}{ Dry wt (g) }} \\
\hline & & & & \multicolumn{7}{|c|}{ Leaf position } & & & & & \\
\hline & & & & $5^{2}$ & 6 & 7 & 8 & 9 & 10 & 11 & & & Leaves & Stem & Total \\
\hline 0 & 82 & 0 & 10.4 & 57 & 68 & 69 & 69 & 71 & 75 & 85 & 702 & 9.6 & 2.42 & 3.27 & 5.69 \\
\hline 0.05 & 64 & 0.2 & 9.6 & 64 & 80 & 80 & 85 & 88 & 89 & 85 & 740 & 8.4 & 2.49 & 2.60 & 5.09 \\
\hline 0.10 & 46 & 1.0 & 9.2 & 65 & 83 & 93 & 89 & 98 & 95 & 91 & 751 & 7.6 & 2.54 & 2.21 & 4.75 \\
\hline 0.20 & 34 & 1.6 & 9.0 & 60 & 79 & 91 & 90 & 99 & 109 & 99 & 762 & 6.0 & 2.60 & 1.91 & 4.51 \\
\hline 0.40 & 15 & 2.8 & 7.6 & 59 & 76 & 91 & 103 & 115 & 111 & $\ldots x$ & 677 & 1.8 & 2.40 & 1.28 & 3.68 \\
\hline \multicolumn{16}{|l|}{ Significance } \\
\hline Linear & ** & ** & * & NS & NS & $*$ & $* *$ & ** & *** & NS & NS & ** & NS & $* *$ & $* *$ \\
\hline Quadratic & $* *$ & $*$ & NS & NS & NS & $* *$ & NS & NS & ** & $*$ & $*$ & NS & NS & $* *$ & NS \\
\hline
\end{tabular}

zThe first leaf being produced after treatment application.

YTotal area of new leaves developed after treatment initiation.

xSome leaves had not expanded fully.

$\mathrm{NS}, *, * *$ Nonsignificant or significant at $\alpha=0.05$ and 0.01 , respectively.

Table 4. Regrowth of golden pothos that were cut back to four leaves 70 days after uniconazole application and grown for 4 additional weeks. Plants were produced one per 0.5-liter pot.

\begin{tabular}{|c|c|c|c|c|}
\hline $\begin{array}{c}\text { Rate of } \\
\text { uniconazole } \\
\text { (mg/pot) }\end{array}$ & $\begin{array}{l}\text { Total stem } \\
\text { length } \\
\text { (cm) }\end{array}$ & $\begin{array}{c}\text { Total leaves } \\
\text { (no.) }\end{array}$ & $\begin{array}{c}\text { Total } \\
\text { leaf area } \\
\left(\mathrm{cm}^{2}\right)\end{array}$ & $\begin{array}{l}\text { Area of } \\
\text { largest leaf } \\
\left(\mathrm{cm}^{2}\right)\end{array}$ \\
\hline 0 & 21.2 & 9.4 & 324 & 53 \\
\hline 0.05 & 5.9 & 10.6 & 463 & 67 \\
\hline 0.10 & 4.1 & 10.6 & 498 & 89 \\
\hline 0.20 & 3.8 & 11.0 & 454 & 73 \\
\hline 0.40 & 3.3 & 13.4 & 481 & 70 \\
\hline \multicolumn{5}{|l|}{ Significance } \\
\hline Linear & *** & $* *$ & * & NS \\
\hline Quadratic & ** & NS & * & $* *$ \\
\hline
\end{tabular}

nate the possible effect of water on water loss from cuttings soaked in an antitranspirant solution in Expt. 1, leaves on stock plants were sprayed on both sides with $5 \%$ Folicote or Stressguard, or water. Cuttings were collected the next day.

Half of these cuttings were planted immediately, while the other half were weighed and placed singly on a bench with 380 umol $\cdot \mathrm{m}^{-2} \cdot \mathrm{s}^{-1}$ maximum PPF and air at 30 to $35 \mathrm{C}$. These cuttings were reweighed after $6 \mathrm{~h}$ and planted. Cuttings were watered as needed but did not receive misting. The experiment was a factorial combination of the above two factors arranged in a randomized complete-block design with four replications. There were five pots, each with a single cutting, in an experimental unit. Plants were grown as in Expt. 1 and similarly evaluated 11 weeks after planting.

Neither antitranspirant nor planting time affected the rate of leaf production, i.e., time to first leaf unfolding (averaging 45 days) and leaf number (averaging 3.5 leaves per shoot). Contrary to the results of Expt. 1, treating stock plants with Stressguard resulted in less total leaf area, shorter stem length, and reduced fresh weight than no treatment, while Folicote had no effect on plant growth (Table 2). Regardless of antitranspirant treatment, all cuttings lost similar amounts of water, $\approx 0.3 \mathrm{~g} / \mathrm{leaf}$, during the 6 $\mathrm{h}$ of delayed planting. Much of the water loss may have been through the two cut-stem surfaces on all cuttings, thus diminishing any possible beneficial effect of antitranspirants in reducing water loss. Nitzsche et al. (1991) reported that the addition of a surfactant to
5\% Folicote solution reduced water loss from detached bell pepper leaves, whereas Folicote by itself did not. Although water stress caused by delayed planting did not affect stem length of golden pothos, it did result in small leaves that contributed to the low shoot weight (Table 2).

Growth retardant (Expt. 3). Golden pothos were grown one per OS-liter square pot filled with Sunshine No. 1 medium containing no bark. Plants were cultured as those in Expt. 1. Twenty uniform plants with four leaves each were selected and given $0,0.05$, $0.1,0.2$, or $0.4 \mathrm{mg}$ uniconazole/pot in 100 $\mathrm{ml}$ of water as soil drenches. Watering was withheld for 2 days following treatment application. There was one plant per pot as an experimental unit, and treatments were replicated five times in a randomized complete block design. After 70 days, shoots were severed above the basal fourth leaf and evaluated. Data collection included stem elongation, leaf count, individual leaf size, starting from basal leaf 5, the length of the youngest fully extended internode, number of actively growing lateral shoots, and leaf and stem dry weights. Linear and quadratic regression analyses were performed on all data.

Pots with remaining plants were moved back to the greenhouse bench and allowed to grow. Additional evaluation, including number of lateral shoots, total leaf count, combined stem length, and total shoot fresh weight, was conducted after 4 weeks.

Stem elongation was drastically reduced as the rate of uniconazole increased (Table 3, Fig. 1). Plants treated with this growth retardant produced fewer (Table 3) but larger leaves (Fig. 1) than the untreated control. The effect of low rates of uniconazole on stem elongation appeared to have diminished significantly with time, as judged by the lengths of the youngest but fully elongated internodes (Table 3). Uniconazole promoted early growth of basal lateral shoots, possibly through reduced auxin level (Hamilton and Law, 1987), which weakened the strong apical dominance in this species. Uniconazole has been found to inhibit lateral shoot development in Plectranthus australis $\mathrm{R}$. Br. (Wang and Blessington, 1990) and hibiscus (Wang and Gregg, 1991); both species branch profusely naturally. Ancymidol, another growth retardant, at 25 to $300 \mathrm{ppm}$ resulted in shorter stems of golden pothos but did not promote lateral shoot growth (McConnell and Poole, 1972).

Because of large but fewer leaves on treated plants, total leaf dry weight was unaffected by uniconazole (Table 3). The smaller total shoot dry weight in treated plants was entirely due to the lower dry weight of stems. Leaves on plants receiving uniconazole had high contrast between the yellow and green areas, possibly due to the increased chlorophyll concentration on an area basis (Wang and Gregg, 1989). As the rate of uniconazole increased, the length of nodal roots also decreased (Fig. 1). The shorter internodes and roots are beneficial to producers because less labor will be needed to shorten them while collecting cuttings. We observed that treated plants used progressively less water at increasing uniconazole levels.

Four weeks after the main shoots were severed, the effect of uniconazole on lateral stem elongation was strong (Table 4); however, differences among the various doses were not drastic. This result suggests that adequate amounts of the growth retardant in the growing media were being absorbed by the roots. Therefore, it became apparent that translocation of uniconazole to the region of stem elongation in the original shoot declined as stems grew longer. The higher leaf count in plants treated with higher doses probably was due to the earlier lateral shoot growth. Uniconazole also resulted in a larger total leaf area and in larger individual leaves on lateral shoots as compared with untreated plants (Table 4). Since producers often cut 
shoots for cuttings and allow plants to grow for several weeks before selling them, uniconazole may be used to increase the aesthetic value of plants by promoting earlier lateral shoot growth and the production of larger leaves and compact plants.

Under the conditions of these experiments, there appears to be little need to apply an antitranspirant to golden pothos leaves to reduce water loss and enhance cutting growth. The parent leaf on a pothos cutting is the primary source for carbohydrate supply. Soaking cuttings in an antitranspirant and growing them without misting probably reduced gas exchange and net photosynthesis (Weller and Ferree, 1978), causing a limited photosynthate supply from the parent leaf to the developing lateral shoot that resulted in slow growth. Uniconazole at doses of 0.05 and $0.1 \mathrm{mg} / 0.5$-liter pot seems appropriate for use on stock plants, whereas from the consumer's viewpoint, the higher doses may be preferred because the large leaves and short internodes yield a fuller plant. Although minimal growth retardation was found in $\mathrm{Hi}$ biscus rosa-sinensis L. cuttings collected from stock plants treated with uniconazole (Wang and Gregg, 1989), we do not know how growth of a cutting from a retarded golden pothos will be affected. Studies are needed to determine whether the application of uniconazole on stock plants will affect cutting growth and postproduction performance of golden pothos.

\section{Literature Cited}

Baggott, A.J. and J.N. Joiner. 1974. Effects of shade, mist and antitranspirant on rooting and nutrient leaching of Ligustrum japonicum and Chrysanthemum morifolium cuttings. Proc. Fla. State Hort. Soc. 87:474-477.

Conover, C.A. 1976. Postharvest handling of rooted and unrooted cuttings of tropical ornamentals. HortScience 11:127-128.

Hamilton, R.H. and D.M. Law. 1987. The effect of S-3307 on the IAA levels in elongation of stem of Alaska pea, p. 313-314. In: D.J. Cosgrove and D.P. Knievel (eds.). Physiology of cell expansion during plant growth. Amer. Soc. Plant Physiol., Rockville, Md.

Martin, J.D. and C.B. Link. 1973. Reducing water loss of potted chrysanthemums with pre-sale application of antitranspirants. J. Amer. Soc. Hort. Sci. 98:303-306.

Martin, J.D. and C.B. Link. 1978. The potential use of antitranspirants in the greenhouse production of chrysanthemum. J. Amer. Soc. Hort. Sci. 103:327-331.

McConnell, D.B. and R.T. Poole. 1972. Vegetative growth modification of Scindapsus aureus by ancymidol and PBA. Proc. Fla. State Hort. Soc. 85:387-389.

Nitzsche, P., G.A. Berkowitz, and J. Rabin. 1991. Development of a seedling-applied antitranspirant formulation to enhance water status, growth, and yield of transplanted bell pepper. J. Amer. Soc. Hort. Sci. 116:405-411.

Poole, R.T. and C.A. Conover. 1988. Storage of philodendron and pothos cuttings. Proc. Fla. State Hort. Soc. 101:313-315.

Wang, Y.T. 1987a. Influence of ancymidol on growth and interior quality of Syngonium podophyllum 'White Butterfly'. HortScience 22:959-960.

Wang, Y.T. 1987b. Effect of temperature, dura- tion, and light during simulated shipping on quality and rooting of croton cuttings. HortScience 2:1301-1302.

Wang, Y.T. 1990. Growth substance, light, fertilizer, and misting regulate propagation and growth of golden pothos. HortScience 25:16021604.

Wang, Y.T. and T.M. Blessington. 1990. Growth of four tropical foliage species treated with paclobutrazol or uniconazole. HortScience 25:202204.

Wang, Y.T. and C.A. Boogher. 1988. Effect of nodal position, cutting length, and root retention on the propagation of golden pothos. HortScience 23:347-349.

Wang, Y.T. and L.L. Gregg. 1989. Uniconazole affects vegetative growth, flowering, and stem anatomy of hibiscus. J. Amer. Soc. Hort. Sci. 114:927-932.

Weller, S.C. and D.C. Ferree. 1978. Effect of a pinolene-base antitranspirant on fruit growth, net photosynthesis, transpiration, and shoot growth of 'Golden Delicious' apple trees. J. Amer. Soc. Hort. Sci. 103:17-19. 